\title{
The Dialectics Between Constitutional Identity and Common Constitutional Traditions: Which Language for Cooperative Constitutionalism in Europe?
}

\author{
Massimo Fichera ${ }^{\star}(\mathbb{D})$ and Oreste Pollicino ${ }^{\star *}$
}

(Received 22 September 2018; accepted 23 January 2019)

\begin{abstract}
This Article revisits the role and function of constitutional identity and common constitutional traditions and claims that the latter have had an increasingly stronger influence on the process of European integration-more than may appear at first sight. In addition, the relevance of common constitutional traditions has not been undermined but, on the contrary, strengthened by the emergence of fundamental rights in EU law and the subsequent conferral of binding force on the Charter of Fundamental Rights. Constitutional identity and common constitutional traditions are part of two discourses-security and fundamental rights-which are an expression of the security of the European project as an overarching frame characterizing the EU as a polity and legal system. After an overview of some of the most important rulings of the Court of Justice of the European Union, this Article concludes by emphasizing the importance of the recent conciliatory attitude recently adopted by the Court of Justice, although the more ambivalent attitude of the Italian Constitutional Court indicates how conflictual features are becoming increasingly important and can no longer be concealed as the EU reaches a more advanced stage of integration.
\end{abstract}

Keywords: European constitutionalism; fundamental rights; transnational law; constitutional identity; common constitutional traditions

\section{A. Introduction}

This Article is based on the following claim: While the definition of constitutional identity is important for the configuration of the EU as transnational law, it needs to be complemented sometimes - as our case study will try to show-by the notion of common constitutional traditions ("CCTs"). This reconstruction can be performed by viewing the security of the European project as a meta-constitutional rationale that has informed the process of European integration from its early stages. Security, as interpreted here, is expressed not only by CCTs but by the principles of primacy, uniformity, and effectiveness of EU law and all other principles and features allowing the EU legal order to assert its autonomy and persist over time. Security does not coincide with mere stability but has an existential connotation. It refers to a set of core values that needs to be protected against any form of identifiable threat. This approach may apply both

\footnotetext{
${ }^{\star}$ Massimo Fichera is Academy of Finland Research Fellow and Adjunct Professor at the University of Helsinki, Faculty of Law.

${ }^{* *}$ Oreste Pollicino is full professor of Constitutional Law, Bocconi University, Milan.
} 
to the national and the EU levels. ${ }^{1}$ This meta-constitutional rationale is expressed by two interacting and overlapping discourses - security and fundamental rights - which can be detected not only in the case law of the courts but also in the practices and activity of the European institutions - although the focus of this Article will be on the former. Yet, security is an ambiguous concept: It has a conciliatory and a conflictual side and reflects the tension between the values of freedom and coercion. This feature, which is visible in the well-known case law on constitutional identity, ${ }^{2}$ is confirmed by the case law on CCTs analyzed in this Article. Moreover, CCTs emphasize a dimension of European integration that goes beyond a purely positivist account.

In order to prove our claim, we will preliminarily show that the notion and role of CCTs, after the season of fundamental rights codification in Europe, are far from irrelevant. They are as crucial as ever, precisely due to such codification.

This Article is structured as follows. First, the notion of the EU as transnational law is unfolded by tying up the concepts of constitutional identity and CCTs within the framework of security. This first part will deal, on a more theoretical ground, with the EU as a laboratory of transnational law where an ever-growing tendency - and temptation - to refer to the language of constitutional identity has emerged.

Against this background, we will argue that the alternative language of CCTs, which is much more pluralistic by nature and closer to the constitutional pluralism narrative, better serves the purpose of regulating inevitable constitutional conflicts in the EU laboratory of transnational law.

The second part, dealing more specifically with CCTs, will attempt to gauge the extent of influence and consideration that the "domestic constitutional factor" has had in the Court of Justice of the European Union's ("CJEU”) most successful achievement, namely that of setting out, in the words of Richard Posner, "a constitutional doctrine by a common law method."3

The analysis in this regard will focus, first, on the development of the process of European integration until the entry into force of the Maastricht Treaty and, second, on the relevance and role of CCTs after the conferral of binding force on the Charter. Thus, the relevant research question is whether, following the season of codification of rights in the EU, the role played by CCTs can be depicted as a chronicle of a death foretold or still has relevance and "constitutional" value.

The question appears to be legitimate, given that it could be argued that one of the most obvious consequences of the adoption and entry into force of the Charter of Fundamental Rights of the European Union ("CFREU" or "Charter") has been a progressive marginalization-or even sidelining - of CCTs, together with the general principles of EU law. According to this argument, such traditions and principles would have ended up playing an exclusively supplementary and ancillary role vis-à-vis a Charter which, after obtaining constitutional status and binding force, would have finally vested the EU with self-sufficiency in the area of fundamental rights. Our aim is to show

\footnotetext{
${ }^{1}$ For example, not only the Court of Justice of the European Union (“CJEU”), but also national courts may act to preserve EU values. From this perspective, we may understand the Italian Constitutional Court's decision No. 170/1984 in which the Court reserved upon itself the power to review internal laws which prevent or compromise the continuing observance of the Treaty. Corte Costituzionale, Case 170/1984, ECLI:IT:COST:1984:170, Judement of 5 June 51984.

${ }^{2}$ See, e.g., ECJ, Case C-441/14, Dansk Industri v. Rasmussen, ECLI:EU:C:2016:278, Judgment of 19 April 2016; Hoejesteret, Case 15/2014, Dansk Industri, acting on behalf of Ajos A/S v. Estate of A, Judgment of 2014 (UfR 2017.824H); Alkotmánybíróság (AB) [Constitutional Court] November 30, 2016, 22/2016 (Hung.). Hungarian decision available at http://hunconcourt.hu/sajto/ news/communication-on-the-interpretation-of-the-fundamental-laws-provision-allowing-the-joint-exercise-of-powers-withthe-other-member-states-through-the-institutions-of-the-european-union; ECJ, Joined Cases C-643 \& 647/15, Slovak, Hungary, Poland v. Council, ECLI:EU:C:2017:618, Judgment of 26 July 2017.

${ }^{3}$ Richard A. Posner, LaW And Legal Theory in England and America 14 (1996) (noting the common law method of judicial interpretation is a method that sees the text as a starting point, which allows judges to create a body of constitutional law according to pragmatic criteria taking account, inter alia, of prior precedents).
} 
instead that-not only despite but, paradoxically, thanks to the Charter-both CCTs and general principles of EU Law can still play a crucial and partially new role in the European integration process.

It will also be shown that CCTs and fundamental rights can be viewed as part of two broader constitutive discourses of European integration-respectively, security and fundamental rightsand inscribed in what can be defined as the meta-constitutional rationale of the security of the European project. These discourses overlap with each other, and it is precisely from their interaction that we can deduce how contradictory the process of European integration can sometimes be.

With regard to the methodology, in principle, two options could be chosen. On the one hand, a synchronic method attempts to capture a snapshot of the impact, which CCTs currently have on the level and form of protection of fundamental rights within the most recent case law of the CJEU.

On the other hand, a diachronic perspective looks at the evolutionary-but also regressionisttendencies, which have characterized the changing role and nature of CCTs over the course of the European integration process while not underestimating the founding period of such process.

Although the second option may be criticized as an "incursion into legal archaeology," it may also be the most appropriate perspective for the enquiry for at least two reasons. First, CCTs have an innate capacity to reveal the historical dimension of constitutionalism by identifying lines of continuity binding the past to the present and the present to the future. Second, precisely on account of the characteristic element highlighted above, referring to a present and a future of CCTs without exploring the reasons underlying the genesis and evolution of that notion would risk focusing too much on the trees while losing sight of the woods, or, even worse, focusing too much on the finger while neglecting the moon.

\section{B. The EU as a Form of Transnational Law}

\section{Overlapping Identities}

Constitutional identity has become a central feature of the EU as a form of transnational law. ${ }^{4}$ While this may not come as a surprise, as EU integration reaches an advanced stage of development, one should not be oblivious to the ambiguities associated with identity and the related feature of conflict.

It has been observed that modern constitutionalism relies on the interplay between identity and difference: A constitutional order necessarily revolves around a predominant identity, with the result of emphasizing certain identities to the expense of others and reducing certain differences. ${ }^{5}$

Identity always deals with the tension between these two poles. This is one of the reasons why the process of constructing and defining identity-and identities-is characterized by contradictions. Some identities might prevail over others if the social and historical context in which they emerge is favorable. In fact, constitutional identity has a dynamic character which results from the interplay of opposing forces pushing either for greater harmony or greater disharmony. ${ }^{6}$ In other words, identity should not be reified but rather viewed as a process whereby an important, yet not exclusive, role is played by the agents performing the identification. ${ }^{7}$ In other words, identification

\footnotetext{
${ }^{4}$ Transnational Law: Rethinking European Law And Legal Thinking (Miguel Maduro et al. eds., 2014) (highlighting the EU as transnational law).

${ }^{5}$ Michel Rosenfeld, Introduction to Constitutionalism, Identity, Difference And Legitimacy: Theoretical Perspectives 3 (Michel Rosenfeld ed., 1994).

${ }^{6}$ Gary JefFrey Jacobsohn, Constitutional Identity 87-88 (2010).

${ }^{7}$ Richard C. M. Mole, Discursive Identities/Identity Discourses and Political Power, in Discursive CONSTRUCTIONS OF IDENTITy In European Politics 10 (Richard C. M. Mole ed., 2007).
} 
should be seen as focusing on identity not as a thing, but as a process in which the act of identifying-relating the individual to the collective dimension-is performed by an agent. ${ }^{8}$

Because constitutional identity is generated and defines itself in contrast with its opposite, what it is not, ${ }^{9}$ identity inevitably: (a) Draws lines of inclusion and exclusion, though they are never neatly defined ${ }^{10}$ and are themselves subject to constant change; and (b) hovers between the complementary and contradictory notions of sameness and selfhood. ${ }^{11}$ In other words, while the textual part of a constitution-its content-may stay the same, its social meaning evolves depending on the context and historical circumstances. Identity as selfhood highlights the reflexive ability of a constitution to define itself over time beyond its mere content. ${ }^{12}$

As a result of (a), a constitutional act always includes just as much as it excludes. This implies a distinction between those who are "inside" and those who are "outside," with the implication that the "outside" is also constitutive of the "inside."13 As a result of (b), the interpretation of the laws on which a constitutional community is based tends to preserve the values and principles that are supposed to lie at the foundation of that community. Thus, a constitutional communityincluding a transnational community — can only exist if it is secure. ${ }^{14}$ Yet, there are different ways a polity can be said to be secure.

Identity is certainly a useful concept in this context. But, as will also be shown in the case study, exclusive reference to the notion of identity can become counterproductive with regard to the final aim of achieving security, as defined above. The reason is that such exclusive reference can "inject" an excessive amount of conflicts and polemics into constitutional discourse, much greater than the physiological degree of conflict embedded in the notion of security.

It should be borne in mind, in this regard, that our approach does not equate security with mere stability; rather, it has an existential connotation. It relates to a set of core values that need to be protected against any form of identifiable threat. This approach may apply both to the national and the EU levels. However, security is an ambiguous notion. As has been mentioned, it necessarily enhances conflict, which is in fact a very important feature of the EU as transnational law. One may add that conflict is enhanced precisely when a polity reaches an advanced, more mature stage of development and the lines of inclusion and exclusion drawn on the basis of values and principles become more evident.

Consequently, this Article suggests the importance of a diachronic perspective when analyzing issues associated with identity. In the context of the EU, characterized by overlapping identities and coordinating legal orders, the problem of the "inside" and "outside" is magnified by the fact that constitutional identity is a notion that can be applied both to the EU and to its constituent parts-the Member States. Each of these elements claims some form of identity and, as a result, defines itself to some extent in opposition to the others. ${ }^{15}$ It should not come as a surprise that the

\footnotetext{
${ }^{8}$ Anna Duszak, Introduction to Us ANd OTHERs: Social Identities Across LANGUAGES, Discourses AND CULTURES 1-28 (Anna Duszak ed., 2002).

${ }^{9}$ Henri Tajfel \& Joseph P. Forgas, Social categorization: Cognition, values, and groups, in SOCIAL COGNITION: PERSPECTIVES ON EVERYDAY UNDERSTANDING 113-40 (Joseph P. Forgas ed., 1981) ("We are what we are because we are not what we are.").

${ }^{10}$ Hans Lindahl, Fault Lines of Globalization: Legal Order and the Politics of A-Legality (2013).

${ }^{11}$ Paul Ricoeur, Oneself as Another (Kathleen Blamey trans., 1992).

${ }^{12}$ Michel Rosenfeld, The Identity of the Constitutional Subject: Selfhood, Citizenship, Culture, and COMMUNity 27 (2010).

${ }^{13}$ JaCQUes Derrida, Positions (Alan Bass trans., 1981) and subsequent elaborations, e.g., ERnESTo LACLAU \& ChANTAL Mouffe, Hegemony and Socialist Strategy: Towards a Radical Democratic Politics (1985).

${ }^{14}$ For more details, see Massimo Fichera, The Foundations of the European Union as a Polity (2018). To avoid misunderstandings, the broad notion of security employed in this work is not related to the area of freedom, security and justice, but to the European constitutional framework as a whole. See also Massimo Fichera, Discursive Constituent Power and European Integration, in The Future of Europe: Political and Legal Integration Beyond Brexit (Antonina Bakardjeva Engelbrekt \& Xavier Groussot eds 2019).

${ }^{15}$ See RosEnFELD, supra note 12 , at 30 :
} 
idiosyncratic vocabulary of national identity has often replaced sovereignty in the development of the EU as a form of transnational law. ${ }^{16}$

Nevertheless, if viewed from the perspective of the "security of the European project"-while preserving an irreducible core ${ }^{17}$ —no constitutional identity can be proclaimed in radical, nationalistic terms. Otherwise, the entire edifice would collapse, notwithstanding the fact that it is premised upon the proclaimed ideas of dialogue and cooperation. Thus, employing the notion of "constitutional identity" is more useful than its more popular counterpart, "national identity." Further, it is important to note that although identification and negation are inherent in the creation and development of identity, constitutional identity incorporates but does not correspond to national identity. ${ }^{18}$

A condition for the existence of an "imagined constitutional community" is that it differentiates itself — through a broader scope-from its corresponding "imagined national community." 19 Yet again, from the perspective of the "security of the European project," we argue here that coexistence of the national and the transnational levels of integration can best be guaranteed through the language of constitutional identity, as long as it is complemented by the second language of CCTs, which aims to build a bridge between constitutional and national identities. ${ }^{20}$ As Jacobsohn points out, CCTs - or, in his words, "traditions and the collective mindset of the people"-determine the boundaries of constitutional change by enabling certain paths of common development and foreclosing others. ${ }^{21}$ In other words, the language of identity represents the conflictual side of security, whereas the language of CCTs can be viewed as its conciliatory side. This is because "a multinational polity like the EU will need to pay heed to the loyalties its citizens feel towards their own national groups if it itself desires to become the object of its citizens' allegiance in order to secure its viability." 22

Undoubtedly, systemic plurality and the need for mutual accommodation are questions that are far from being solved once and for all. As we move from the familiar environment of domestic law to EU law, they test the legitimacy of the EU's authoritative claim as a polity and legal order, touching upon its very foundations.

Security as interpreted here therefore entails a normative claim: The political and legal existence of the EU in times of crisis can be better preserved by viewing primacy, autonomy, uniformity, and effectiveness not from an "either/or" identitarian angle-which would single out European identity and constitutional/national identity as diametrically and antagonistically

\footnotetext{
The constitutional self must also produce an identity in opposition to — and hence by negating — constitutional others both within the polity ... and beyond the boundaries of the polity against other constitutional selves with different identities or with identities from which the prevailing constitution within the polity must be differentiated.

${ }^{16}$ Joseph H. H. Weiler, On the Power of the Word: Europe's Constitutional Iconography, 3 INT'L J. ConsT. L. 173, 184 (2005) (noting "to protect national sovereignty is passé; to protect national identity by insisting on constitutional specificity is à la mode").

${ }^{17}$ This constitutional core may be variously identified. See Daniel Sarmiento, The EU's Constitutional Core, in NATIONAL CONSTITUTIONAL IDENTITY AND EUROPEAN INTEGRATION 177 (Alejandro Saiz Arnaiz \& Carina Alcoberro Llivina eds., 2013). However, while reference may be made, for example, to Articles 2, 3, and 4 TEU or to the Preamble to the Treaty of Lisbon, it should be pointed out that the dynamic character of the constitutional core goes beyond a mere textual account and reaches out to the societal dimension.

${ }^{18}$ Elke Cloots, National Identity, Constitutional Identity, and Sovereignty in the EU, 45 NeTH. J. LeGAL PHIL. 82 (2016). However, the author argues that moral concerns should lead to an interpretation of Article 4 (2) TEU as requiring respect for national rather than constitutional identity, which, being based on a claim to sovereignty on behalf of the Member States, is a source of conflict. The argument of this Article is, instead, that conflict is unavoidable but can be better managed through the notion of "common constitutional traditions."

${ }^{19}$ Rosenfeld, supra note 12 , at 29.

${ }^{20}$ Elke Cloots, National Identity in EU Law (2015) (noting that the legal and political value inherent in the national identity clause must be recognized).

${ }^{21}$ JACOBSOHN, supra note 6, at 89 (quoting Bagehot).

${ }^{22}$ Cloots, supra note 20 , at 90 .
} 
opposed-but from a "both/and" conciliatory angle. This conciliatory angle acknowledges conflict and existential threats but also attempts to overcome them, to ensure the survival of the European project. The construction of CCTs as a discourse is essential for these purposes.

Accordingly, the protection of fundamental rights should occur to the extent that their recognition is instrumental to ensuring the principles of primacy, autonomy, uniformity, and effectiveness-but only as long as such principles are viewed in relative, not absolute, terms.

\section{The Seasons of CCTs in the European Integration Process \\ I. The Past}

In light of what has been said so far, it is possible to observe how the CJEU's construction of the security and fundamental rights discourses has taken place gradually, but relentlessly. ${ }^{23}$ Moreover, these discourses have almost always intertwined and reinforced each other.

In fact, it should not be surprising that, before Costa E.N.E.L. and van Gend, the first occasion on which a question arose concerning respect for a constitutional tradition of a Member State-albeit in relation to the ECSC Treaty-was in 1958. There, ${ }^{24}$ the CJEU held that it had no competence to make a finding or take any account of the violation of fundamental principles set forth in the Grundgesetz (German constitution) by Community acts. Upon closer consideration, this also has a paradoxical aspect if one attempts to reflect on the fact that the first time the CJEU acted in the manner of a Constitutional Court, it did so in order to exclude the relevance and validity on Community level of the constitutional tradition of a Member State. ${ }^{25}$

Moreover, it would appear to be no coincidence that this season of European impermeability to domestic constitutional law corresponds to the period of European integration in which the CJEU proved to be more inclined to make specific and detailed comparative law analysis-which it would not do in later periods - of the Member States' legislation.

Consider, for example, the reasoning in the Algera judgment of $1957 .{ }^{26}$ After an introductory discussion of the possibility of revoking unlawful administrative acts, and having clarified that this was "a problem ... which is familiar in the case-law and learned writing of all the countries of the Community, but for the solution of which the Treaty does not contain any rules," the Court concluded that "unless the Court is to deny justice it is therefore obliged to solve the problem by reference to the rules acknowledged by the legislation, the learned writing and the case-law of the member countries." 27

And in that case, the Court did so in a systematic and detailed manner.

All of this occurred, as mentioned above, before the CJEU "pulled out of the hat" the doctrines of the primacy and direct effects.

From that time onwards, the argumentative priorities of the CJEU were evidently destined to be overturned. Previously, it had in fact been very risky for the Court to reference the existence of any requirement for the Community institutions to act in a manner that did not violate the provisions of national constitutions. ${ }^{28}$ But once the principle of primacy had been established, it became

\footnotetext{
${ }^{23}$ See, e.g., CJEU, C-6/64, Costa v. E.N.E.L., ECLI:EU:C:1964:66, Judgment of 15 July 1964; CJEU, C-26/62, van Gend en Loos, ECLI:EU:C:1963:1, Judgment of 5 Feb. 1963.

${ }^{24}$ CJEU, Case C-1/58, Stork v. High Authority, ECLI:EU:C:1959:4, Judgment of 4 Feb. 1959.

${ }^{25} \mathrm{Id}$.

${ }^{26}$ CJEU, Joined Cases C-7/56, 3/57 to 7/57, Algera v. Common Assembly of ECSC, ECLI:EU:C:1957:7, Judgment of 12 July 1957.

${ }^{27} I d$. at 55 .

${ }^{28}$ As Joseph Weiler pointed out in connection to Stork, "in the absence of a clearly established doctrine of supremacy, there would be little to stop the review of Community actions under national constitutional law from expanding to any national norm." See Joseph H. Weiler, Eurocracy and Distrust: Some Questions Concerning the Role of the European Court of Justice in the Protection of Fundamental Human Rights Within the Legal Order of the European Communities, 61 WASH. L. REV. 1103 , 1114 (1986).
} 
essential for the CJEU to suddenly discover an interest in the protection of fundamental rights and to construct a common constitutional framework for such protection, even when no such framework actually existed. From the 1970s onwards, the fundamental rights discourse has been a necessary legitimacy-and autonomy-enhancing tool in the Court's arsenal. A constant effort to boost the EU's credentials as a distinct creature of transnational law has led to an assertion of autonomy: Either vis-à-vis its Member States, ${ }^{29}$ or vis-à-vis international law. ${ }^{30}$ Such autonomy implies that the interpretation of fundamental rights that lies at the core of the EU legal system must be in line with its structure and objectives. ${ }^{31}$ These moves may be interpreted as part of the EU's ongoing strategy of self-justification and self-empowerment.

During this period, the reference to CCTs loses its value as a comparative constitutional analysis in order to take on the nature of a rhetoric tool employed for the purposes of the above-mentioned EU strategy of self-justification.

As a matter of fact, a careful comparative analysis of the constitutional experiences of the Member States might have risked undermining the Court's new argumentative priorities. It was therefore no coincidence that thereafter the Court only very rarely adopted the almost arithmetical analysis that characterized its reasoning in the Algera judgment.

By contrast, the highly relevant relationship between the CJEU mandate to enforce EU law primacy and the attention paid by the same Court to CCTs has very often been underestimated.

In this regard, it is of great benefit to consider the CJEU's reasoning in the Internationale Handelsgesellschaft case. ${ }^{32}$ First, it is worth recalling the Luxembourg judges' statement that the question of the compatibility of Community law with the constitutional law of the Member States was irrelevant for the purposes of assessing the validity of Community law itself. ${ }^{33}$ This statement is entirely inscribed in the logic of the CJEU's activity, aimed at maintaining the uniformity and efficacy of EU law. Those goals would be undermined whenever Member States, upon declaring the incompatibility of EU law with national constitutional values, would challenge the validity of EU law and disapply it. In other words, we can interpret this ruling as an expression of the meta-constitutional security rationale: The Court may be seen as arguing that the Community legal system's survival and self-preservation depended upon a certain degree of autonomy from the domestic legal systems. However, the same judges took-almost in an attempt to mitigate the "subversive" scope of this principle-a step of equally fundamental relevance, at least for the purposes of this discussion.

\footnotetext{
${ }^{29}$ ECJ, Case C-29/69, Stauder v. Stadt Ulm, ECLI:EU:C:1969:57, Judgment of 12 Nov. 1969; Bundesverfassungsgericht [BVerfG] [Federal Constitutional Court], Case 11/70 Internationale Handelsgesellschaft mbH v. Einfuhr- und Vorratsstelle für Getreide und Futtermittel, ECLI:EU:C:1970:114, Judgment of 17 Dec. 1970; ECJ, Case C-4/73, Nold KG v. Commission, ECLI:EU:C:1974:51, Judgment of 14 May 1974. More recently, see ECJ, Case C-399/11, Melloni v. Ministerio Fiscal, ECLI: EU:C:2013:107, Judgment of 26 Feb. 2013.

${ }^{30}$ ECJ, Joined Cases C-402 \& 415/05, Kadi \& Al-Barakaat Int'l Foundation v. Council and Comm'n, ECLI:EU:C:2008:461, Judgment of 3 Sept. 2008; ECJ, Case C-160/09, Ioannis Katsivardas - Nikolaos Tsitsikas v. Ypourgos Oikonomikon, ECLI:EU: C:2010:293, Judgment of 20 May 2010.

${ }^{31}$ Internationale Handelsgesellschaft, Case 11/70 at para. 3; Joined Cases 402/05 and 415/05 Kadi and Al-Barakaat, Joined Cases C-402 \& 415/05 at paras. 281-85.

${ }^{32}$ Internationale Handelsgesellschaft, Case 11/70.

${ }^{33} I d$. at para. 3. Judges have already expressly underlined that:
}

Recourse to the legal rules or concepts of national law in order to judge the validity of measures adopted by the institutions of the Community would have an adverse effect on the uniformity and efficacy of Community law. The validity of such measures can only be judged in the light of Community law. In fact, the law stemming from the Treaty, an independent source of law, cannot because of its very nature be overridden by rules of national law, however framed, without being deprived of its character as Community law and without the legal basis of the Community itself being called in question. Therefore the validity of a Community measure or its effect within a Member State cannot be affected by allegations that it runs counter to either fundamental rights as formulated by the constitution of that State or the principles of a national constitutional structure. 
More precisely, in addition to stressing that respect for fundamental rights should be regarded as an integral part of the general principles of Community law, the Court stipulated for the first time that the protection of fundamental rights at the Community level, "inspired by the constitutional traditions common to the Member States, must be ensured within the framework of the structure and objectives of the Community." 34 On the one hand, focus is given to the relevance of fundamental rights - the fundamental rights discourse; on the other hand, the Court points out that their protection can only take place if the structural and teleological configuration of the European project is preserved-the security discourse.

In an attempt to strike a balance between the values of freedom and coercion within the EU polity, the Court emphasizes that it is not prepared to make concessions regarding the enforcement of the rule of primacy. Nevertheless, it reassures the Member States that such enforcement would not jeopardize and neglect their constitutional traditions.

With regard to the first step cited above, according to which protection for fundamental rights is "inspired by the constitutional traditions common to the Member States," it may be asserted that the supremacy of Community law over national law, at least within the area of protection for fundamental rights, has never been stated in clear absolute terms by the CJEU. At a time when such supremacy seemed to reach its highest apex-extending beyond the limits laid down in the constitutions of the Member States - in some sense, it was going to be "relativized" by the Court of Justice's unprecedented reference to national constitutional traditions as an indirect limit on that primacy.

The fact remains that the purportedly reassuring effect aspired to by this last CJEU case law in the area of fundamental rights started to become characterized by a strictly reactive connotation. ${ }^{35}$

With regard to the second step mentioned in Internationale, according to which protection for fundamental rights "must be ensured within the framework of the structure and objectives of the Community," this amounts to an initial enunciation avant la lettre of the position, which would be stated by the Court much more clearly nine years later in Hauer, according to which CCT exercise limited influence on the development of the case law on fundamental rights.

The Court reiterated in Hauer that:

[T] he question of a possible infringement of fundamental rights by a measure of the Community institutions can only be judged in the light of Community law itself. The introduction of special criteria for assessment stemming from the legislation or constitutional law of a particular Member State would, by damaging the substantive unity and efficacy of Community law, lead inevitably to the destruction of the unity of the common market and the jeopardizing of the cohesion of the Community. ${ }^{36}$

In other words, after expressly considering the constitutional law of nine Member States-an event which was more unique than rare - the CJEU ultimately decided that the best law-or the constitutional tradition that was best placed to realize the objectives of the Community-was to be found in the proportionality principle. That principle, derived from Germany's constitutional tradition, was to be construed as a general principle of EU law. ${ }^{37}$

Thus, the debate on CCTs appeared to have been resolved during the golden age of the CJEU by a rhetorical sleight of hand of a highly symbolic nature. The Court sought legitimacy for its

\footnotetext{
${ }^{34} I d$. at para. 4.

${ }^{35}$ The reference is related to the additional case law which has added, as a source of inspiration for the protection of fundamental rights, the rules of the relevant international treaties in the field of human rights which the Member States have ratified-Nold, Case C-4/73 - including the ECHR, which is in a privileged position. See CJEU, Case C-36/75, Rutili v. Ministre de l'intérieur, ECLI:EU:C:1975:137, Judgment of 28 Oct. 1975.

${ }^{36}$ Cass., 13 dicembre 1979, Giust. 1979, 14 (It.).

${ }^{37}$ See G. Gaja, Aspetti problematici della tutela dei diritti fondamentali nell'ordinamento comunitario, in RIV. DIR. INTERNAZ. 627 (1988) (see comment in main body of article).
} 
argument in support of the putative link between the solution proposed within the case before it and the solution allegedly existing within the constitutional experience of the Member States. This meant that the Court could continue to do what it had initially been able to do undisturbed - namely, in the now legendary words of Eric Stein, "tucked away in the fairyland Duchy of Luxembourg and blessed, until recently, with the benign neglect by the power that be and the mass media." ${ }^{8}$

\section{The Present, After the Entry into Force of the Charter: Common Constitution Traditions Today, Still a Meaningful Concept?}

As we have attempted to illustrate in the previous section, prior to the launch of the fundamental rights codification process, CCTs were never authentic sources of law. Instead, they were instruments possessing a strong rhetorical element as part of the security discourse. It is now necessary to consider how the act of fundamental rights codification in Europe has affected the status quo.

A distinction may be drawn between two phases. The first starts with the proclamation of the Charter in 2001. The second (still ongoing) starts after the entry into force of the Treaty of Lisbon, which gave also effect to the Charter as a legally binding instrument.

One remark must be made about the first period, defined as one of "limbo."

During this period, CCTs - and even more so the general principles of Community law, which, as mentioned above, constitute the supranational sublimation of those traditions - provided the interpretative leverage, albeit ambivalently, that the CJEU was able to exploit to take steps that placed the constitutional tolerance of the Member States under serious strain.

Such exploitation occurred in the 2005 Mangold judgment, for example. ${ }^{39}$ In a creative- bordering on manipulative - interpretation, the CJEU asserted the direct applicability of the general principle of non-discrimination on the basis of age, thus greatly expanding the scope of EU law. Roman Herzog's strongly-worded editorial—commenting on the Court's decision in the heat of the moment-was emblematic of the inseparable connection between the application of the general principle and the identification of the CCTs underlying that principle. Yet it was also emblematic of the reaction that the Court's interpretative activism, which was based precisely on that connection, engendered among the Member States. The title of the editorial was eloquent in its simplicity: "Stop the European Court of Justice." 40

According to the former President of the Convention responsible for drafting the CFR, this reference to the principle of non-discrimination on the basis of age as a general principle of EU law should have been reflected, if not inspired, by the CCTs of the Member States. By contrast, Herzog argued that:

[T]his 'general principle of community law' was a fabrication. In only two of the then 25 member states - namely Finland and Portugal - is there any reference to a ban on age discrimination, and in not one international treaty is there any mention at all of there being such a ban, contrary to the terse allegation of the CJEU. Consequently, it is not difficult to see why the CJEU dispensed with any degree of specification or any proof of its allegation. To put it bluntly, with this construction which the CJEU more or less pulled out of a hat, they were acting not as part of the judicial power but as the legislature. ${ }^{41}$

\footnotetext{
${ }^{38}$ Eric Stein, Lawyers, Judges, and the Making of a Transnational Constitution, 75 AM. J. INT'L L. 1 (1981).

${ }^{39} \mathrm{CJEU}$, Case C-144/04, Mangold v. Helm, ECLI:EU:C:2005:709, Judgment of 22 Nov. 2005.

${ }^{40}$ Roman Herzog \& Lüder Gerken, Stop the European Court of Justice, EUOBSERVER (Sept. 10, 2008).

${ }^{41}$ Based on these arguments, it is likely that Herzog himself did not share the conclusions of the most recent decision of CJEU, Case C-555/07, Seda Kücükdeveci v. Swedex GmbH \& Co. KG, ECLI:EU:C:2010:21, Judgment of 19 Jan. 2010, in which the Luxembourg judges stated that:
}

In those circumstances, it for the national court, hearing a dispute involving the principle of non-discrimination on grounds of age as given expression in Directive 2000/78, to provide, within the limits of its jurisdiction, the legal 
Against this background, has the CCTs' highly transformative evolutionary process come to an end after the entry into force of the Charter? Have CCTs effectively exhausted their task in the age of bill(s) of rights?

Our answer is a negative one. Far from having had the effect of pushing back CCTs, the attribution of legally binding force to the Charter has actually led-at least potentially and for sure paradoxically - to the opposite result: Enabling those traditions to emerge more forcefully.

To start, it is necessary to provide a quantitative figure. A recent publication on this issue noted that reference to CCTs has arisen more frequently within the case law of the Court than it did during the pre-Charter period; moreover, figures have increased exponentially over the last ten years. $^{42}$

How specifically has this CCTs' second drawing manifested itself?

One might reply that this has occurred in at least two ways.

The first is significant on the rhetorical plane-almost as an optical illusion-and appears to be inherent to the CJEU's argumentative use of CCTs. The second manifestation concerns a new role which, precisely thanks to the entry into force of the Charter, now appears to be capable of characterizing the post-Lisbon CCTs' life.

As far as the first aspect is concerned, the CJEU's spring $2015^{43}$ decision that, for the first time, annulled an entire act of secondary EU law on the grounds that it contrasted with the Charter, appears to be emblematic, as illustrated below.

First, the Irish High Court asked the CJEU whether the provisions of the Directive on the retention of traffic data by e-communications operators ${ }^{44}$ was compatible with the proportionality principle laid down by Article 52(1) of the Charter, and whether they violated the rights to privacy, protection of personal data, freedom of expression, and good administration laid down respectively in Articles 7, 8, and 11 of the Charter. Second, the Austrian Constitutional Court, which had been apprised of numerous constitutional actions filed directly by private individuals seeking the annulment of the national law implementing the Directive, sent a preliminary reference asking whether the procedures for collecting data provided for under the Directive were compatible with the rights to privacy, protection of personal data, and freedom of expression protected by the CFR. That Court also asked whether the European legislative framework respected the essence of the right to protection of personal data, and whether the retention of data was compatible with CCTs and with Article 8 of the European Convention on Human Rights ("ECHR”).

The CJEU decision specifically struck down Directive 2006/24/EC on the ground that its provisions regarding data retention, which were intended to pursue the general interest of

protection which individuals derive from European Union law and to ensure the full effectiveness of that law, disapplying if need be any provision of national legislation contrary to that principle.

${ }^{42}$ See Stefania Ninatti, Ieri e oggi delle tradizioni costituzionali comuni: le novità nella giurisprudenza comunitaria, in SCRitTi In MEMORIa Di Alessandra Concaro 533 (Giuseppe D’Elia, Giulia Tiberi \& Maria Paola Viviani Schlein eds., 2012). See, e.g., ECJ, Joined Cases C-20 \& 64/00, Booker Aquaculture Ltd \& Hydro Seafood GSP Ltd v. Scottish Ministers, ECLI:EU:C:2003:397, Judgment of 10 July 2003; ECJ, Case C-265/87, Schräder v. Hauptzollamt Gronau, ECLI: EU:C:1989:303, Judgment of 11 July 1989; ECJ, Case C-71/02, Herbert Karner Industrie-Auktionen GmbH v. Troostwijk GmbH, ECLI:EU:C:2004:181, Judgment of 25 Mar. 2004; ECJ, Case C-441/14, Dansk Industri v. Rasmussen, ECLI:EU: C:2016:278, Judgment of 19 Apr. 2016; ECJ, Case C-147/08, Römer v. Freie und Hansestadt Hamburg, ECLI:EU: C:2011:286, Judgment of 10 May 2011.

${ }^{43}$ CJEU, Joined Cases C-293 \& C-594/12, Digital Rights Ireland Ltd v. Minister for Communications, Marine \& Natural Resources \& Others \& Kärntner Landesregierung \& Others, ECLI:EU:C:2014:238, Judgment of 8 Apr. 2014.

${ }^{44}$ Council Directive 2006/24 of Mar. 15, 2006, On the Retention of Data Generated or Processed in Connection with the Provision of Publicly Available Electronic Communication Services or of Public Communications Networks and Amending Directive 2002/58/EC, 2006 O.J. (L 105) 54 (EC). 
combating terrorism, were found to violate Articles $7^{45}$ and $8^{46}$ of the Charter, concerning respect for private and family life and the protection of personal data respectively. The Court's decision in Digital Rights Ireland provided an opportunity to reflect on how the CJEU's supposed recovery of CCTs is at times more rhetorically functional than effective. The CJEU tried to give the impression that it had taken on the task of representing CCTs at the European level in the area of data protection. These traditions were supposedly recognized by Article 8 of the Charter, whose task was merely to Europeanize the CCTs connected to data protection.

In other words, the Court sought to give the impression, through an artful optical illusion, ${ }^{47}$ that the Charter itself was exclusively a codifying constitution, to use the language of Lawrence Lessig. ${ }^{48}$ The Charter's role would merely involve cataloguing and schematizing existing rules; specifically, "codifying" at the European-level evolutionary developments-in this case relating to the common constitutional traditions.

Still, the Charter has an ambivalent nature. It is undoubtedly a codifying constitution, but it is not limited to this. It also incorporates much of the second category identified by Lessig, namely what he defines as a transformative constitution. ${ }^{49}$ This is characterized by the Charter's tendency to alter the status quo, innovating essential aspects of the legal culture and thus reaching beyond existing CCTs. As noted earlier, the security of the European project is pursued through an operation of self-justification, which implies some degree of creativity. This operation takes place, first, by allowing change in the interpretation of law-while also preserving the values and principles at the basis of integration - and, second, by including those values and principles, which are supposed to be shared, and excluding all the others.

The tendency to also be a transformative constitution may be observed if one considers that Article 8 of the Charter does not amount to the projection of a shared constitutional principle onto European law. ${ }^{50}$

As to the second issue highlighted above, related to the new role potentially played by CCTs due to the entry into force of the Charter, an important element should be pointed out. The choice to codify the protection of rights - which had previously been protected only through case law, thanks to the vehicle of general principles of European Union law-at the para-constitutional level has, almost paradoxically, favored the emergence of a new role for CCTs. They have been revitalized in the case law of the CJEU. In fact, as will be shown below, the existence of the Charter has made CCTs more prominent in the reasoning of the Court.

\footnotetext{
${ }^{45}$ Charter of Fundamental Rights of the European Union art. 7, June 7, 2016, 2016 O.J. (C 202) 389,395 [hereinafter "Charter"]. According to Article 7: "Everyone has the right to respect for his or her private and family life, home and communications."

${ }^{46}$ Charter, supra note 45 , at 395 . According to Article 8:

1. Everyone has the right to the protection of personal data concerning him or her.

2. Such data must be processed fairly for specified purposes and on the basis of the consent of the person concerned or some other legitimate basis laid down by law. Everyone has the right of access to data which has been collected concerning him or her, and the right to have it rectified.

3. Compliance with these rules shall be subject to control by an independent authority.

${ }^{47}$ In this regard, the preamble to the Charter provided it with excellent support in referring to the Charter as a simple reaffirmation of the rights originating from the common constitutional traditions. See Charter, supra note 45, at 393 ("This Charter reaffirms, with due regard for the powers and tasks of the Community and the Union and the principle of subsidiarity, the rights as they result, in particular, from the constitutional traditions and international obligations common to the Member States.").

${ }^{48}$ Lawrence Lessig, Code: And Other Laws of Cyberspace (1999).

${ }^{49} \mathrm{Id}$. at 313 .

${ }^{50}$ In reality, only the Netherlands-following the 1983 constitutional amendment-Spain-in Article 18.4 of its constitution-and a few constitutions from Central Eastern Europe provide an express constitutional framework for data protection.
} 
More precisely, minor interpretative gaps gave the CJEU an easy time carrying out highly creative interpretative operations, in which traditions play an essential role, in its most recent case law. These gaps result from the fact that, as far as the scope of protection for the rights in play is concerned, the moment of writing ${ }^{51}$ has not always ensured that these rights maintain the same scope following the shift from the unwritten domain-general principles and constitutional traditions - to the written domain of the Charter. This means that a general principle, as inspired by CCTs, is capable of having a scope or an expansive potential that is broader than the codified version of the right in the Charter. ${ }^{52}$

In other words, the argumentative reference within the Court's reasoning to the general principle - for example, in relation to the principle of good administration ${ }^{53}$-is potentially capable of being used as a Trojan horse to circumvent the limit provided for under Article 51 with regard to its application within EU law. This capability is precisely due to a greater expansive scope, compared to the formulation of the same right within the Charter.

To put it in simplistic terms, general principles can apply to situations that fall beyond the scope of the corresponding rights contained in the Charter.

It must also be noted that on some occasions the Court has "forgotten" to cite the Charter at all and has referred exclusively to the corresponding general principle and to the CCTs out of which it results. An emblematic case in this regard is El Dridi ${ }^{54}$ in which the Luxembourg Court invited the referring court-when resolving the dispute pending before it- to take due account of the principle of the retroactive application of a more lenient penalty, "which forms part of the constitutional traditions common to the Member States." 55 The Court did so without referring to Article 49(1) of the Charter, which codifies that principle and would have been applicable in this specific case alongside the corresponding general principle.

It is thus no coincidence that the CJEU has tailored its reasoning and adjusted its argumentative instruments to this goal.

This is an argumentative exercise which, if considered within its proper context, becomes even more interesting in that it shows the CJEU as almost a "two-faced Janus" regarding the interpretation of Article 51 of the Charter. On the one hand, the Court has adopted an extremely cautious - if not restrictive - approach, in order to reassure the Member States - and in particular their constitutional courts - that the Charter will not be applied broadly beyond the scope of EU law. On the other hand, the Court is pushing precisely in the opposite direction, by using the highly effective passepartout of general principles and CCTs.

Confirmation of this new role of CCTs as a trump card that is capable of expanding the scope of the Charter beyond the boundaries laid down by Article 51 may be found in the $D E B$ case,${ }^{56}$ along

\footnotetext{
${ }^{51}$ Cesare Pinelli, Il momento della scrittura: Contributo al dibattito sulla costituzione europea (2002).

${ }^{52}$ The consideration as to whether there is a potential hiatus - with reference obviously to the scope of protection for a particular right-between the expansive scope of the Charter and the corresponding general principle also has significant implications in terms of concrete application. The British and Polish opt-outs, which besides are marginal in their extent, are focused exclusively on the scope of the Charter and could not by contrast be applied to the general principles distilled out of the common constitutional traditions unless those principles are attributed, as must be hoped, with conceptual and operational autonomy. See also Leonard F.M. Besselink, The Protection of Fundamental Rights post-Lisbon: The Interaction between the EU Charter of Fundamental Rights, the European Convention on Human Rights (ECHR) and National Constitutions, General Report at the XXV FIDE [Fédération Internationale pour le Droit Européen] Congress Tallinn (May 31, 2012).

${ }^{53}$ Herwig C.H. Hofmann \& Bucura C. Mihaescu, The Relation between the Charter's Fundamental Rights and the Unwritten General Principles of EU Law: Good Administration as the Test Case, 9 EUR. CONST. L. ReV. 73(2013) (see comment in main body of article).

${ }^{54}$ CJEU, Case C-61/11, Hassen El Dridi, ECLI:EU:C:2011:268, Judgment of 28 April 2011.

${ }^{55} \mathrm{Id}$. at para. 61.

${ }^{56} \mathrm{CJEU}$, Case C-279/09, DEB Deutsche Energiehandels- und Beratungsgesellschaft mbH v. Bundesrepublik Deutschland, ECLI:EU:C:2010:811, Judgment of 22 Dec. 2010.
} 
with the fairly creative application of Article 47-on the right to an effective remedy-by the Court in that case. ${ }^{57}$

The problem that arose in this case concerned the contrast between EU law and German law. German law did not allow a legal person, other than in exceptional cases, to receive free legal aid in order to bring legal actions in the event that it did not dispose of its own resources because under the relevant German legislation, that right was reserved to natural persons. This meant that the applicant company was unable to bring a damages action against the German state on the grounds that it had not transposed an EU directive within the prescribed time limit.

The national judge's question was simple: Is the principle of an effective judicial remedy-also expressed by Article 47 of the Charter - capable of precluding a national provision that, by failing to provide financial assistance for bringing legal actions to legal persons, de facto does not allow such persons to benefit from the principle of effective judicial relief?

This interesting factual question shows that, when the CJEU lacks CCTs, it is able to follow an alternative path to the one visible in Digital Rights Ireland. This argumentative path involves the recourse, as a supplementary tool, to the recognition by the European Court of Human Rights of the level of consensus between states regarding the way a specific right is protected.

In light of the above, it will come as no surprise that although the national court expressly referred to Article 47 of the Charter, the CJEU started by referring to the corresponding general principle. It asserted that the requirement to protect the principle of effective judicial relief amounts to "a general principle of EU law stemming from the constitutional traditions common to the Member States." 58

This opening statement placed the principal question beyond the scope of the Charter; however, it did not yet resolve three significant interpretative obstacles that impaired the CJEU's ability to answer the national court's question in the affirmative.

First, it was necessary to avert an outcome that risked resulting in a literal interpretation of Article 47 of the Charter. This provision again refers to "everyone"-except in the third paragraph, which refers less specifically to "those" - and appears to exclude the possibility that the right recognized thereunder may be recognized to a legal person. The Court acknowledged that "no indication is given as to whether such aid must be granted to a legal person or of the nature of the costs covered by that aid" but added that such a "provision must be interpreted in its context, in the light of other provisions of EU law, the law of the Member States and the case law of the European Court of Human Rights. ${ }^{59}$ As it has been asserted elsewhere, ${ }^{60}$ the reference to contextbased interpretation is always a fairly clear indication that the court is engaging in judicial activism. It will come as no surprise that the Community courts reached the conclusion that legal persons cannot, by principle, be precluded from the scope of Article 47 of the Charter. The Court pointed out, inter alia, that on the one hand, the Commission had stressed in its intervention that the term "everyone" used in the first two paragraphs of Article 47 could refer to individuals, but that from a purely linguistic point of view it did not exclude legal persons. On the other hand, it emphasized that although the explanations relating to the Charter were not clear in this regard, confirmation of such an interpretative approach may be found in the use of the term "Person" in

\footnotetext{
${ }^{57}$ Charter, supra note 45, at 403. According to Article 47:

Everyone whose rights and freedoms guaranteed by the law of the Union are violated has the right to an effective remedy before a tribunal in compliance with the conditions laid down in this Article. Everyone is entitled to a fair and public hearing within a reasonable time by an independent and impartial tribunal previously established by law. Everyone shall have the possibility of being advised, defended and represented. Legal aid shall be made available to those who lack sufficient resources in so far as such aid is necessary to ensure effective access to justice.

${ }^{58}$ DEB Deutsche, Case C-279/09 at para. 29.

${ }^{59} I d$. at para. 39 .

${ }^{60}$ Oreste Pollicino, Legal Reasoning of the Court of Justice in the Context of the Principle of Equality Between Judicial Activism and Self-Restraint, 5 GERMAN L.J. 283, 283-317 (2004).
} 
the German language version of Article 47-as opposed to the term "Mensch," used in numerous other Charter provisions where the intention is to refer exclusively to natural persons.

Having thereby creatively overcome the first obstacle-the literal wording of Article 47 of the Charter - a second, equally problematic issue remained. In this specific case, the Court needed to identify CCTs that could be used as fuel to propel the construction of a general principle concerning the grant of free legal aid to legal persons. While, as indicated at the outset by the Court, there was undoubtedly a common constitutional basis for the principle of an effective judicial remedy, the Court could not fail to admit that it was short on constitutional "fuel" with regard to the more specific principle of free legal aid for legal persons. No optical illusion is capable of concealing what was made clear by the Advocate General in his opinion (para. 76-80). The Court itself stated that "examination of the law of the Member States brings to light the absence of a truly common principle which is shared by all those States as regards the award of legal aid to legal persons."

The need to rectify this shortcoming forced the CJEU to look to the relevant case law of the European Court of Human Rights. Following a careful analysis of that case law, the Luxembourg Court held that-regarding the relevant legal traditions of the members of the Council of Europe - the Strasbourg Court did not, as a matter of principle, exclude the possibility of extending the grant of free legal aid to legal persons, although that possibility "must be assessed in the light of the applicable rules and the situation of the company concerned."

This amounts to a rather interesting exercise in judicial creativity, involving an expansion of CCTs, looking towards the "greater" Europe. It is evident that, depending on the judicial body that acknowledges the relevant legal traditions-and especially the relevant geographical area on which it focuses - this may or may not result in the emergence of a shared constitutional factor.

In this case, the implicit logic of the CJEU's reasoning is as follows. Absent an internal source of CCTs, it may be useful-and in fact decisive- to link up with the-much more extensiveexternal source, which the Strasbourg Court could not avoid drawing on when concluding that entitlement to free legal aid also extended to legal persons, which could be considered to fall within the scope of Article 6(1) of the Convention.

One final "insignificant" detail remained, which prevented the CJEU from finding a violation of EU law. This area of law, as has been noted, ${ }^{61}$ and has not been subject to harmonization on an EU level. In particular, the relevant German law prohibiting it had by no means been adopted as part of any form of transposition of EU law. This area laid outside the scope of EU law and it would have been very difficult to apply the Wachauf case law ${ }^{62}$ here, given that there was no connecting factor whatsoever that could give rise to any requirement to transpose EU law into national law.

The impact on the sphere of European law was defined by the principle of effectiveness - in this case, broadly interpreted. It seems that the principle of effectiveness may also play the role of a special "gear" between the national and European systems, used to extend the field of application of guarantees of fundamental rights. ${ }^{63}$

The outcome is not infallible, in view of this manipulation carried out over the three stages described above. The CJEU resolved the question by declaring that: (a) The principle of an effective judicial remedy, as enshrined in Article 47 of the Charter, must be interpreted to the effect that legal persons may not be precluded from invoking it; and (b) legal aid granted thereunder may specifically include an exemption from the payment of an advance on court costs and/or legal representation.

\footnotetext{
${ }^{61}$ Marek Safjan, Areas of Application of the Charter of Fundamental Rights of the European Union: Fields of Conflict? (Eur. Univ. Inst. LAW Working Papers; 2012/22). The sphere of European law impact was in this case defined by the principle of effectiveness, broadly interpreted here. As it seems, the principle of effectiveness may also play the role of a special gear between the national and European system, used in order to extend the field of application of fundamental rights' guarantees.

${ }^{62}$ CJEU, Case C-5/88, Wachauf v. Bundesamt für Ernährung und Forstwirtschaft, ECLI:EU:C:1989:321, Judgment of 13 July 1989.

${ }^{63}$ Safjan, supra note 61.
} 
Against this background, it is quite clear that CCTs - far from becoming subject to a process of marginalization and progressive sidelining within the case law of the Court following the proclamation and subsequent entry into force of the CFR, in terms of the theory of interpretation ${ }^{64}$ play an essential role in the CJEU's reasoning. This has been facilitated by the absence of any overlap between the scope of some of the rights provided for under the Charter and of the corresponding general principles. The minor interpretative gaps that emerge from this lack of overlap have allowed the Court to expand the scope of application of EU law. Within this scenario, constitutional traditions play an essential role as part of the security discourse-not only as domestic fuel in the construction of general principles, but also in particular as a Trojan horse on which the interpretative, or rather manipulative, activity of the CJEU focuses-in order to circumvent the limit laid down by Article 51 of the Charter.

\section{Relevance of the Common Constitution Traditions in the (Near) Future}

Finally, with regard to the possible future development of the language of common constitutional traditions, such language seems very useful to represent a valid option to surpass the alternative language of constitutional identity as the main ingredient in the judicial conversation between the CJEU and constitutional courts in Europe.

In order to present this argument, a step back is necessary.

In the 2004 Omega $^{65}$ decision, the CJEU moved from the "plural" to the "singular" in its interpretative stance towards CCTs. The Court's shift from determining those common traditions for the purposes of applying the majoritarian activism approach to considering the individual constitutional identity of the single Member State raised hopes of a possible shift from absolute to relative primacy in the CJEU case law. Those hopes were further fostered by the adoption of the clause on respect for national identity contained in Article 4(2) of the EU Treaty.

In a way, the above-mentioned provision has been taken too seriously by those who believe that, despite the original intent of the drafters ${ }^{66}$ and the relevant case law of the CJEU, ${ }^{67}$ the concept of "national identity" is identified with the concept of "constitutional identity and framed within the discourse of the Court of Justice ("ECJ") and national constitutional courts' different claims to sovereign authority." 68

This reading was crucial in fueling the already existing "new identity control" season in the case law of the German Constitutional Court. ${ }^{69}$ The request of a preliminary ruling in Gauweiler, ${ }^{70}$ far

\footnotetext{
${ }^{64}$ Nevertheless, the Court has not taken the lead from the Charter in order to promote traditions in terms of the normative aspect of the theory of sources of law.

${ }^{65}$ CJEU, Case C-36/02, Omega v. Oberbürgermeisterin der Bundesstadt Bonn., ECLI:EU:C:2004:614, Judgment of 14 Oct. 2004.

${ }^{66}$ Barbara Guastaferro, Beyond the Exceptionalism of Constitutional Conflicts: The Ordinary Functions of the Identity Clause (NYU Sch. of Law Jean Monnet Ctr., Working Paper 01/2012). If the preparatory works as part of the European Convention which drafted this Charter are considered, this clause is in actual fact more relevant to a question of competence than a question of appreciating the value of the internal constitutional experience. The reasons why the constitutional identity clause was introduced, in fact, relate to the safeguarding of the fundamental political and constitutional structures. As noted by Guastaferro, the assumption that the purpose of the clause is that of applying in exceptional cases of conflicts between EU law and domestic constitutional law - in an attempt to narrow the scope of application of the supremacy doctrine-has to be challenged; the potential for a use of the clause in governing the ordinary functioning of EU law should be, on the contrary, highlighted.

${ }^{67}$ It is sufficient to consider the judgment of the CJEU in Sayn-Wittgestein, CJEU, Case C-208/09, Sayn-Wittgenstein v. Landeshauptmann von Wien, ECLI:EU:C:2010:806, Judgment of 22 Dec. 2010. Indeed, the ECJ has never identified the constitutional identity clause enshrined in Article 4(2) TEU as the privileged arena to deal the multilevel protection fundamental rights in its case law.

${ }^{68}$ Armin von Bogdandy \& Stephan Schill, Overcoming Absolute Primacy: Respect for National Identity under the Lisbon Treaty, 48 Common MKT. L. ReV. 1417, 1419 (2011).

${ }^{69}$ Bundesverfassungsgericht [BVerfG] [Federal Constitutional Court], Lissabon-Urteil, 2 BvE 2/08 (June 30, 2009), https:// www.bundesverfassungsgericht.de/entscheidungen/es20090630_2bve000208.html.

${ }^{70}$ Bundesverfassungsgericht [BVerfG] [Federal Constitutional Court], 2 BvR 2728/13 (June 21, 2016), https://www. bundesverfassungsgericht.de/SharedDocs/Entscheidungen/EN/2016/06/rs20160621_2bvr272813en.html.
} 
from being an expression of cooperative constitutionalism, represented the apex of polemic constitutional patriotism in which the language of constitutional identity played an absolute protagonist role. This language was not constrained by any set of essentials that are themselves compliant in general outline with the basic values of Article 2 of the Treaty on European Union ("TEU"). This move towards the conflictual side of security-in the constitutional identity conversation between the German Constitutional Court and the CJEU-has involuntarily supported the wind of populism, which is blowing across Europe and from which courts-including constitutional and supreme courts-are not immune. The language of constitutional identity has been manipulatively borrowed, as the Hungarian case shows very well, by non-independent constitutional courts $^{71}$ who wish to totally distort the original meaning of constitutional identity and make it substantially overlap with the will of the government. ${ }^{72}$

Against this background, the language of CCTs, as an expression of the conciliatory side of security, could instead be more promising for the future of judicial conversations in Europe.

The Italian Constitutional Court ("ICC") is a pioneer speaker of this new language, as its first move in the recent Taricco saga seems to confirm. ${ }^{73}$ Strangely enough, the case in which the new attitude has emerged is one in which the same Court used, for the first time ever ${ }^{74}$ and in the context of the relationship between the domestic and the EU legal orders, the phrase "constitutional identity." 75 This confirms how the dialectics between CCTs and constitutional identity generates ambiguities and contradictions in the relationship between courts. In this major case, the ICC referred a preliminary question to the CJEU: Whether its previous judgment in Taricco $^{76}$ - which, in line with Article 325 of the Treaty on the Functioning of the Union ("TFEU”), required Italian criminal courts to set aside domestic statute of limitations rules whose effect was to undermine the prosecution of tax crimes against the financial interests of the EU-ought to be applied even if it conflicted with the constitutional principle of legality in criminal law. The ICC underlined how this constituted a fundamental principle of the Italian constitutional system ${ }^{77}$ and flagged its concern for the practical application of the previous ECJ ruling. ${ }^{78}$

Nevertheless, the ICC recognized the importance of the primacy of EU law ${ }^{79}$ and endeavored to prod the CJEU to revisit its previous ruling by underlying the fact that the principle of legal certainty constitutes "a common requirement to the constitutional traditions of the member states, is present in the system of protection of the ECHR, and as such it enshrines a general principle of EU law." ${ }^{\circ}$ While the ICC kept the possibility of invoking the counter-limits doctrine against the future ruling of the CJEU open, it refrained from embracing a confrontational position premised on the idea that the constitutional identity of Italy was undermined by the EU. Rather, the ICC stressed the correspondence between the constitutional tradition of Italy and the values

\footnotetext{
${ }^{71}$ Gábor Halmai, The Hungarian Constitutional Court and Constitutional Identity, VerfassungsBlog (Jan. 10, 2017), https://verfassungsblog.de/the-hungarian-constitutional-court-and-constitutional-identity.

${ }^{72} I d$. In the case of the Hungarian Constitutional Court decision, Gábor Halmai astutely noted "[t]he will of the government not to have any refugees."

${ }^{73}$ Corte Cost., 23 Nov. 2016, n. 24/2017, Racc. uff. corte cost. 2016 (It.).

${ }^{74}$ In fact, before the recent Taricco judgment, the phrases "constitutional identity" and "national identity" never appear from a quantitative point of view in the case law of the Constitutional Court ("CC"). Contrary to the BVerfG, which has developed over time constitutional identity review on top of fundamental rights- and democracy-based judicial review of EU acts, the CC has focused its counter-limit doctrines exclusively to the field of the protection of fundamental rights. This approach is evident in the other relevant CC decisions dealing with the relation between the national and the EU legal order, including Frontini and Granital.

${ }^{75}$ Corte Cost., n. 24/2017 \$6.

${ }^{76}$ CJEU, Case C-105/14, Taricco and Others, ECLI:EU:C:2015:555, Judgment of 8 Sept. 2015.

${ }^{77}$ Corte Cost., n. $24 / 2017 \$ 5$.

${ }^{78} \mathrm{Id}$.

${ }^{79}$ Id. $\$ 8$.

${ }^{80}$ Id. $\$ 9$.
} 
underpinning the project of European integration and asked the CJEU to recognize the common constitutional heritage linking the EU and its member states. True, the ICC specified that the principles that came into question in Taricco deal with the constitutional identity of Member States. Yet, the ICC particularly emphasized the importance of CCTs, including both the national and European ones. In the ICC's view, the existence of a CCT does not prevent each Member State from adopting a specific understanding of the same principle-most notably where the relevant area of law has not been subject to harmonization. The ICC, without also neglecting the relevance of constitutional identity, focuses more on the notion of constitutional tradition(s). At the same time, however, one of the main outcomes of the Taricco saga is that the protection of the financial interests of the EU-a common good of the EU as a whole-is ensured. One consequence of this reconfiguration is the replacement of the idea of the one and only possible authoritative ruling of the CJEU with that of a cooperative interpretative enterprise, according to which several possible-but by no means all possible-interpretations of EU law by the relevant national courts are admitted.

In other words, concerning constitutional conflict, the ICC seems to propose an alternative language with regard to the protection of the untouchable core of the constitutional legal order. This is compared to the identity-based language spoken by the German Constitutional Tribunal in Gauweiler, for example. It is the language of the necessary protection of constitutional tradition, which turns out to be a European legal concept by design, and for sure is more in line with the current season of cooperative constitutionalism in Europe. ${ }^{81}$

It is not only a formal, linguistic difference but also a substantive one. The constitutional tradition is, by definition, pluralistic in nature, whereas the reference to constitutional identity, by design, is not. As it has been pointed out, the ICC reasoning shifts from the national constitutional tradition to the European one, seeking to prod the CJEU to reconsider its previous judgment in light of values which are part of the European constitutional heritage. ${ }^{82}$

Even if the conclusions of the Advocate General Bot $^{83}$ were not promising in this respect, ${ }^{84}$ the CJEU benefitted from the ICC cooperative assist. More precisely, with this judgment, ${ }^{85}$ the Court revisited its previous stance by taking the request to disapply the domestic provisions affording broader protection to fundamental rights seriously, in order to make the protection of the financial interests of the EU conditional upon the respect of the rights of individuals. The ECJ thus proclaims the existence of inherently pluralistic constitutional traditions of Member States; this way, Article 6(3) of the TEU, even if not explicitly mentioned, is definitely preferred to Article 4(2) of the TEU with a view to providing a more elaborate understanding of the principle of legality than that adopted in Taricco I.

The CJEU thus explored three different and equally relevant profiles of the principle of legality: Foreseeability, precision, and non-retroactivity of the applicable criminal law. All these profiles, in the CJEU's view, are given importance in both the EU legal order and in national legal systems. These are then applicable, in the Italian legal order, to the limitation rules for criminal offences relating to the value added tax ("VAT"). In fact, the Italian Republic, before the adoption of

\footnotetext{
${ }^{81}$ However, see Corte Cost., 7 novembre 2017, n. 269/2017, Racc. uff. corte cost. 2017 (It.), in which the ICC, partially contradicting ECJ, Case C-106/77, Amministrazione delle finanze dello Stato v. Simmenthal, ECLI:EU:C:1978:49, Judgment of 9 Mar. 1978, argued that ordinary judges must refer a question for preliminary ruling first to the ICC itself whenever a simultaneous violation of the Charter and the Constitution takes place. Even in those cases, the EU norm is directly effective.

${ }^{82}$ For a similar perspective with regard to the potential role played by the CCT as basis for an alternative language to the identity based one, see M. Graziadei \& Riccardo Decaria, The "Constitutional Traditions Common to the Member States" in the Case-law of the European Court of Justice: Judicial Dialogue at its Finest, in Rivista Trimestrale Di DiritTo PubBLiCO 949 (2017).

${ }^{83}$ CJEU, Case C-42/17, Criminal proceedings against M.A.S., M.B., ECLI:EU:C:2017:564, Opinion of 18 July 2017.

${ }^{84}$ Oreste Pollicino \& Marco Bassini, The Opinion of Advocate General Bot in Taricco II: Seven "Deadly" Sins and a Modest Proposal, Verfassungsblog (Aug. 2, 2017), https://verfassungsblog.de/the-opinion-of-advocate-general-bot-in-taricco-iiseven-deadly-sins-and-a-modest-proposal.

${ }^{85}$ CJEU, Case C-42/17, Criminal proceedings against M.A.S., M.B., ECLI:EU:C:2017:936, Judgment of 5 Dec. 2017.
} 
Directive 2017/1371 — on the fight against fraud to the Union's financial interests by means of criminal law-was free to provide rules in its legal system-like the ones defining offenses and the determination of penalties - as part of substantive criminal law, thereby subject to the principle that offenses and penalties must be defined by law (para. 45).

First, as to foreseeability, the CJEU deduces from the case law of the European Court of Human Rights on Article 7(1) of the ECHR that "provisions of criminal law must comply with certain requirements of accessibility and foreseeability, as regards both the definition of the offence and the determination of the penalty."

Second, the CJEU points out that the requirement that the applicable law must be precise means that:

[T] he law must clearly define offences and the penalties which they attract. That condition is met where the individual is in a position, on the basis of the wording of the relevant provision and if necessary with the help of the interpretation made by the courts, to know which acts or omissions will make him criminally liable.

Third, the principle of non-retroactivity of the criminal law prevents courts, in the course of criminal proceedings, from imposing "a criminal penalty for a conduct which is not prohibited by a national rule adopted before the commission of the alleged offence or aggravate the rules on criminal liability of those against whom such proceedings are brought."

As a result, the CJEU attaches a broader significance to the principle of legality as part of the CCTs of Member States and as enshrined in Article 49 of the Charter. The consequences of this more convincing construction of the principle of legality are very important if one compares the outcome of Taricco II to the ruling in Taricco I.

In other words, the principle of legality is given enhanced strength not merely by virtue of the protection guaranteed by the Charter and the ECHR but mostly as a result of its configuration as a CCT.

The CJEU specified in Taricco II-M.A.S. and M.B.- that the Taricco rule is not applicable before the publication of the same judgment and is thus not applicable in the pending proceedings before the referring judges. Indeed, in both cases, the facts occurred prior to September 8, 2015, so the applicability of Articles 160(3) and 161(2) of the Criminal Code, and the consequent time-barring of the relevant crimes, was admitted pursuant to the M.A.S. and $M . B$. judgment.

Since the CJEU completely changed its approach in the two Taricco judgments-it was much more cooperative and open to the reasoning of the ICC in the Taricco II decision-it might have been tempting to predict that such a decision would have been welcomed and promptly enforced by the ICC. Yet, this would have been a wrong prediction. More precisely, in its latest judgment ${ }^{86}$ - in light of the clarification provided by Taricco II-considered that all questions raised by the referring courts were unfounded because the "Taricco rule" was to be held inapplicable in the cases pending before the Court.

But the Judgment did not end here. It has been stressed above that, in Taricco II, the CJEU's reasoning reveals a new season of cooperative constitutionalism in Europe, according to which the language of constitutional traditions-pluralistic and tolerant by design-was going to definitely take the place of the much more constitutional, patriotic-based language of constitutional identity. This was also thanks to the ICC's assist with its request of primary ruling (with Order No. 24/2017).

Surprisingly enough, it is difficult, or impossible, to find traces of the same language of CCTs in the ICC decision No. 115/2018, which followed the Taricco II judgment. It seems, by contrast, that

\footnotetext{
${ }^{86}$ Corte Cost., 10 aprile 2018, n. 115/2018, Racc. uff. corte cost. 2018 (It.), https://www.cortecostituzionale.it/documenti/ comunicatistampa/CC_CS_20180601103714.pdf.
} 
the ICC decision under review is drenched in what appears to be an emerging post-Lisbon constitutional identity narrative. It may be a formalistic statement, but the reference to constitutional identity is present twice in the judgment (paragraphs 5 and 11) whereas the reference to constitutional traditions is nowhere to be found.

Based on the premise that it enjoys a monopoly in upholding fundamental rights, the ICC does not limit itself to considering the questions put forward by the referring judges as inadmissible (para 10). Accordingly, the ICC opts for a more drastic solution and-independently of whether the crimes were committed before or after September 8, 2015-considers that the degree of precision postulated by Article 25(2) of the Italian Constitution precludes the application of the Taricco rule, as clarified in Taricco II.

The Taricco rule is thus inapplicable to facts before the publication of the Taricco I ruling and, as a result, does not apply to the proceedings pending before the referring judges.

More precisely, despite acknowledging the CJEU's power to interpret EU law uniformly, the Italian Court still argued that Article 325 of the TFEU does not comply with the requirements of specificity and clarity under domestic law.

Although the Court did not trigger its counter-limits explicitly, because it claimed that its ruling is perfectly in line with both domestic law and EU law-thus reserving for itself the power to review EU law in certain circumstances-this judgment still reflects the conflictual side of the meta-constitutional security rationale and confirms its ambiguity.

\section{Outline of the Final Findings of the Analysis}

In conclusion, to answer the question posed at the outset, it certainly still makes sense today to reflect on the topicality and utility of CCTs. In fact, despite the darkest forecasts, they have still survived at the time of writing. Indeed, as this Article has attempted to demonstrate, they are still in excellent health.

Two key features associated with CCTs — and the general principles of the EU-which followed the Charter's entry into force, support this hypothesis.

First, the case law of the Court gives CCTs a new lease on life in a creative way. This is because there are minor interpretative gaps between the scope of protection of a right under the Charter and the scope of protection of the same right when construed as a general principle, through the reference to CCTs of the Member States. As a consequence of those interpretive gaps, the recent case law of the CJEU has had an easy time carrying out highly creative interpretations. These gaps are generated by the fact that rights do not always maintain the same scope when put in writing, following the transition from the unwritten domain of general principles and constitutional traditions to the written text of the Charter. This means that a general principle, as inspired by CCTs, is capable of having a scope-or a potential — that is broader than the codified version of the same right in the Charter. Thus, the Court's reference to general principles may turn out to be a sort of Trojan horse, working to circumvent the limit set out under Article 51 of the Charter with regard to its application within EU law. In simple terms, general principles can have effect beyond the scope of the corresponding rights contained in the Charter.

As we have seen, a good example of this dynamic is provided by the attitude of the CJEU in the enforcement of the principle of good administration beyond the scope of application of Article 41 of the Charter.

The second potential role played by CCTs after Lisbon can be framed as the development of a new language - precisely, that of CCTs - to be used by the CJEU and constitutional courts as an alternative to the identity-based language, which is currently gaining ground in the present 
scenario of judicial interaction in Europe. The latter language is based on a constitutionalpatriotic interpretation of Article 4, paragraph 2 of the TEU. ${ }^{87}$

National identities, in a broader sense, can be considered as counterweights to CCTs. Yet, they are part of the materials upon which these traditions are built. If national identities contribute to the making of national constitutional traditions in the field of fundamental rights, they indeed contribute to create the common traditions as well. National identities can therefore be considered the bricks needed to build CCTs - to the extent that they are common among the Member States - while they become counterweights to the dynamic potential of said traditions when they begin to differ one from the other. In this sense, they are controversial and have a double nature. From this perspective, CCTs - most notably if framed as a pluralistic and "open" notion-can be considered as a possible antidote to the nationalist posture. References to CCTs can help to achieve the famous ideal of "united in diversity." They stress what is common and thus unifying, while at the same time respecting and accommodating national differences. Against this background, the language of CCTs can facilitate judicial conversations in Europe and foster a much more cooperative constitutionalism as an alternative to the conflict-based language of constitutional identity. Several possible, but by no means all possible, interpretations of EU law by the relevant national courts may be admitted, yet they remain within a common mind frame.

A pioneer of this new language, as we have seen, has been the ICC in its preliminary reference to the CJEU in the Taricco saga. ${ }^{88}$ The ICC held that the principles that came into question in Taricco concern the constitutional identity of Member States. Nevertheless, the ICC emphasizes the importance of the CCTs, both at the national and European levels. For the ICC, the existence of CCTs does not strip Member States of the possibility of adopting a specific understanding of the same principle, especially where the relevant area of law has not been harmonized. With its emphasis on CCTs, the ICC advances a language that provides an alternative to the identity-based language endorsed by the German Constitutional Tribunal, for instance, in Gauweiler. It is the language of the necessary protection of CCTs, which turns out to be a European legal notion, better suited to the stage of cooperative constitutionalism in Europe.

This is a substantial difference; it should not be dismissed as merely a formal and linguistic one. The notion of constitutional tradition is by definition pluralistic in nature, whereas the reference to the constitutional identity is hardly so. The ICC reasoning shifts from the national constitutional tradition to European ones to prod the ECJ to reconsider its previous judgment in light of values that are part of the European constitutional heritage. This approach paid off with the second Taricco decision of the CJEU.

Article 6(3) of the TEU, referring to fundamental rights as they result from the constitutional traditions common to Member States, could, as partially shown by the Taricco saga, prove a more appropriate approach than the appeal to the national identity clause enshrined to Article 4(2) of the TEU. However, the tension between the language of CCTs and the language of constitutional identity - respectively, the conciliatory and conflictual side of security-is also visible in the recent ruling of the ICC in reply to the CJEU decision. This tension and related ambiguity is likely to persist for a long time.

Why did the ICC feel the need to clarify with such emphasis its view related to the radical contrast with the constitution of the Taricco rule if, in order to end the saga, it could have been enough to acknowledge the "clarification" of the CJEU in M.A.S. and M.B.?

\footnotetext{
${ }^{87}$ The European Union shall respect the equality of Member States before the Treaties, as well as their national identities, inherent in their fundamental structures, political and constitutional, inclusive of regional and local self-government. It shall respect their essential State functions, including ensuring the territorial integrity of the State, maintaining law and order, and safeguarding national security. In particular, national security remains the sole responsibility of each Member State.

${ }^{88}$ Strangely enough, this approach emerged in the same case where the Court used, for the first time ever, the notion of constitutional identity in the context of the relation between the domestic and the EU legal orders-there is no previous reference to it, even in the Frontini [no. 183/1973] and Granital [no. 170/1984] cases.
} 
The impression is that a lot has to do not only with the vertical relationship with the CJEU but also with the horizontal relationship with ordinary judges.

In other words, the ICC views the cooperative relationship between the CJEU and ordinary judges as a threat to the role and power which should characterize a constitutional court in a system of centralized constitutional adjudication, with regard to the protection of fundamental rights.

The ICC is clearly not indifferent to this risk. This is the reason why the ICC wants to deliver a decision with erga omnes effects.

Although the CJEU has never clarified in Taricco II which judge-the Constitutional Court or the common judges - has to verify the compatibility of the Taricco rule with the principle that offenses and penalties must be defined by law, the ICC rules that it has an exclusive competence to carry out this control, because a supreme principle of the Italian constitutional order is at stake (para. 8).

Even without expressly recalling it, the ICC seems to align itself with the obiter dictum laid down in its judgment No. 269/2017 (para. 5.2). ${ }^{89}$ In that obiter, the constitutional judges, after Taricco II and quoting that judgment, held that "it may therefore occur that the violation of an individual right infringes, at once, upon the guarantees enshrined in the Italian Constitution and those codified by the EU Charter of Fundamental Rights, as recently occurred in reference to the principle of the legality of crimes and punishments," and added that:

[W] here a law is the object of doubts concerning the rights enshrined in the Italian Constitution or those guaranteed by the EU Charter in those contexts where EU law applies, the question of constitutionality must be raised, leaving in place the possibility of making a referral for a preliminary ruling for matters of interpretation or of invalidity of Union law, under Article 267 [of the] TFEU.

In a way, this is an explicit message to the national judges who should think twice before bypassing the ICC in the attempt to foster their privileged communication channel with the CJEU.

More precisely, the message reflected in the most recent ICC rulings seems to be addressed to the Italian Court of Cassation, the court of last resort in Italy. There is a growing emerging battle between the two courts in the field of multilevel protection of fundamental rights. In fact, the Court of Cassation seems reluctant to raise, as requested by the ICC, the question of constitutionality.

If anything, this demonstrates that the tension between security and fundamental rights, as illustrated in this Article, is not only present at the more visible level of the interaction between constitutional courts and the CJEU but also involves ordinary courts. The nature of transnational law, as it were, is that of penetrating the deepest levels of domestic legal systems and generating conflicts. The challenge for the future of the EU legal system is finding a way to address and manage such conflicts as effectively as possible in times of crisis.

\section{E. Conclusive Remarks}

In the light of the results of the analysis carried out, rather than of a death foretold, the chronicle concerned should tell the story of a transfiguration of the role and nature of the concept of constitutional tradition. This cannot come as any surprise if it is considered that one of its essential characteristics lies in its incessant process of becoming and transforming, as a kind of constitutional work in progress, which is never equal to itself. This is entirely in line with the nature of discourses, which are by definition dynamic and constantly evolving.

\footnotetext{
${ }^{89}$ Corte Cost., 7 novembre 2017, n. 269/2017, Racc. uff. corte cost. 2017 (It.).
} 
Besides, a consideration of the role and nature of constitutional traditions that brings out the dynamic dimension as their privileged - or rather natural — habitat will enable us to stress a second aspect that is closely related to this first: The temporal interconnection binding together past, present, and future in relation to CCTs.

Also, the outcome of this case could have been no different if one reflects on the etymology of the term "tradition," which inevitably evokes the tradition as a form of transmission and tradere as a composite of trans and dare.

At this juncture, it appears to be more relevant to focus on the prefix rather than the verb, because the reference to "trans" enables one to appreciate the idea of transmission through time-while it can also mean going beyond a specific temporal dimension-and hence updating the nature and scope of traditions as bearers of new grounds for protection, including where there is discontinuity with the past. This is precisely what has occurred in relation to the new role played by constitutional traditions in the wake of the entry into force of the Nice Charter.

Besides, Martin Krygier was already ahead of his time in skillfully arguing the need to rediscover the current relevance of traditions and, more generally, on the bridge they build between the past and present. He stressed that "we use the language of a [legal] tradition when we attempt to describe how legal past is relevant to the legal present. It is about the power of the past-in-thepresent." 90

Ultimately, the idea of continuity through change, associated with the meta-constitutional rationale of security, is able to explain several features of the European project. The EU system of protection of equality and rule of law is premised upon the functioning of the security and fundamental rights discourses, ensuring the survival and further development of the EU project. In fact, our focus on process and discourses, rather than on static notions of EU law, provides a holistic and dynamic picture of European integration. Not only are CCTs-integrating constitutional identity - and fundamental rights an expression of the two above-mentioned constitutive discourses of European integration, but these discourses overlap with each other, and it is precisely this interaction that highlights the contradictions in the process of European integration. Yet, the overall aim of this work is not to conceal or understate the relevance of conflicts for EU constitutionalism, but rather to analyze them from a broader angle-one that avoids focusing merely on the dimension of disintegration, but also places emphasis on the dimensions of integration and commonality. Clearly, the "we" of the European process of integration is a "we" that constantly needs to be reinstated. The CJEU and national courts are only some of the actors involved in this collective operation of self-justification.

${ }^{90}$ Martin Krygier, Law as Tradition, 5 L. \& PHIL. 237 e. (1986) (see comment in main body of article).

Cite this article: Fichera M, Pollicino O (2019). The Dialectics Between Constitutional Identity and Common Constitutional Traditions: Which Language for Cooperative Constitutionalism in Europe?. German Law Journal 20, 1097-1118. https:// doi.org/10.1017/glj.2019.82 